UNITED STATES DEPARTMENT OF THE INTERIOR

J. A. Krug, Secretary

GEOLOGICAL SURVEY W. E. Wrather, Director

\title{
MAGNETIC SURVEY AND GEOLOGY OF THE EASTERN AND SOUTHEASTERN PARTS OF THE IRON RIVER DISTRICT IRON COUNTY, MICHIGAN
}

By

Harold L. James and Kenneth L. Wier

Prepared with the cooperation of the Geological Survey Division, Michigan Department of Conservation 


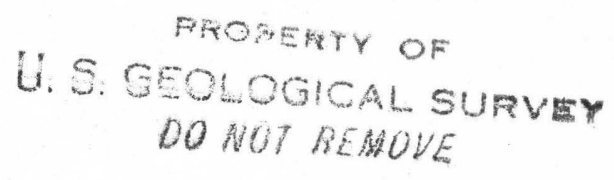

MAGNETIC SURVEY AND GEOLOGY OF THE EASTERN AND SOUTHEASTERN PARTS OF THE IRON RIVER DISTRICT IRON COUNTY, MICHIGAN

By

Harold L. James and Kenneth L. Wier

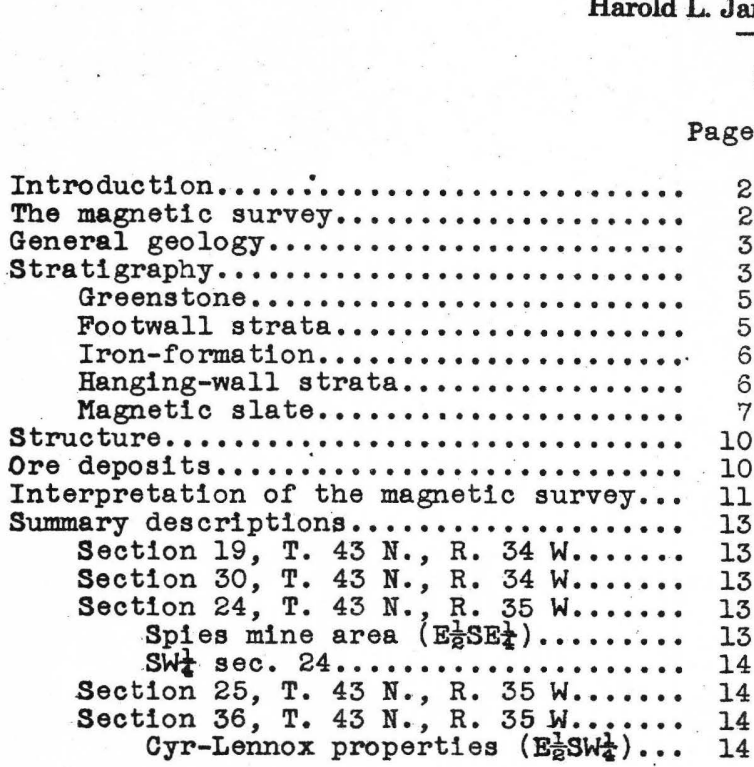

CONTENTS

Page

Summary descriptions (continued)

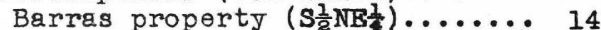

Bengal-Tuliy area (sEt) ......... 14

Section 1, T. 42 N., R. 35 W....... 15

Caspian mine area (NE⿺辶) ....... 15

Morgan exploration (NW $\mathrm{SE}_{\frac{1}{4}}$ ).... 15

Cottrell exploration (NE

Fogarty mine (SEtSEt)........ 15

Section 12, T. 42 N., R. 35 W..... 15

Section 5, T. 42 N., R. 34 W....... 16

Section 6, T. 42 N., R. 34 W....... 16

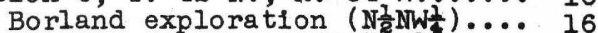

Corry exploration (NES SW

Berkshire mine (NW $W^{\frac{1}{4}}$ )........ 16

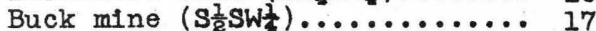

Section 7, T. 42 N., R. 34 W....... 17

Baltic mine (NW $\left.W^{\frac{1}{4}}\right) \ldots \ldots \ldots \ldots . . .17$

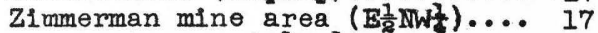

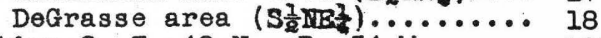

Section 8, T. 42 N., R. 34 W....... 18

Section 9, T. $42 \mathrm{~N}$, R. 34 W....... 18

ILLUSTRATIONS

Page

Plate 1. Map showing magnetic data and inferred geology in the eastern part of the Iron River district, Iron County, Michigan *

2. Map of magnetic data in the southeastern part of the Iron River district, Iron County, Michigan *

3. Map showing inferred geology of the southeastern part of the Iron River district, Iron County, Michigan *

4. Geologic cross sections in the eastern and southeastern parts of the Iron River district (to accompany Plates 2 and 3 ) *

Figure 1. Index map of Iron County, Michigan, showing areas covered by preliminary

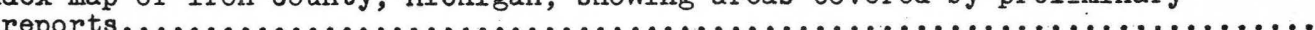

TABLES

Page

Table 1. Stratigraphic chart summarizing characteristics of the iron-formation and

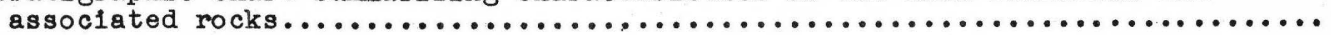

* Avaliable for purchase, Director, Geological Survey (see page 18). 


\section{INTRODUCTION}

The Iron River-crystal Falls district, which is in the northern peninsula of Michigan, has been under study by the U. S. Geological Survey, in cooperation with the Geological Survey Division of the Michigan Department of Conservation, for several years. Preliminary reports have been issued on the Mineral Hills area, I/ the Ice Lake-Chicagon Creek area,2/ and the Crystal Falls-Alpha area (two reports), 3 and a report on the central part of the Iron River district is in preparation.4/ The present report is thus the fifth of a series of reports issued in advance of a more formal publication in which the results of the entire study will be integrated. These preliminary reports serve a dual purpose; they permit critical evaluation of geologic concepts by other geologists and by actual exploration prior to the final publication, and they permit release of factual information, such as the magnetic data, sooner than would otherwise be possible. The reports are entirely preliminary in nature and do not include discussion of theoretical concepts, the results of microscopic study of the rocks and ores, nor an appraisal of pertinent literature.

This report describes an area of about nine square miles east and southeast of the town of Iron River; it includes the towns of Caspian, Gaastra, and stambaugh. Within the area is one producing group of mines, the Buck group, comprising the Buck, Fogarty, Berkshire, Baltic, Zimmerman, and DeGrasse properties, from which 708,324 tons of iron ore were shipped in 1947 by Plckands, Mather and Co. Some of the workings of the spies mine are in the northern part of the map area, but the shaft is outside the area considered in this report. Other properties that have been productive in the past are the Caspian, Bengal, and Tully. The Bengal-Tully mine is now being dewatered by the M. A. Hamna Co., and it is expected that mining will be resumed in 1948. The ore throughout the area is soft, red, non-Bessemer hematite. Some of that produced from the Bengal mine was highly manganiferous.

I) Dutton, C. E., Park, C. F., Jr., and Balsley, J. R., Jr., General character and succession of tentative divisions in the stratigraphy of Mineral Hills district, Iron River, Iron County, Michigan: U. S. Gool. Survey Preliminary Report, 1945.

2) James, H. L., Clark, L. D., and Smith, L. E., MagnetIc survey and geology of the Ice Lake-Chicagon Croek area, Iron County, Michigan: U. S. Geol. Survey Preliminary Report 3-213, 1947.

3/ Pettijohn, F. J., Goology of the Crystal Falls-Ālpha iron-bearing district, Iron County, Michigans U. S. Gool. Survey Preliminary Map No. 3-18l, 1947. Pottijohn, F. J., Magnetic and goologic data of part of the Crystal Falls-Alpha iron district, Iron County, Michigan: Michican Dept. of Cons., Gol. Survey Div., 1948.

4/ Dutton, C. E., Goology of the contral part of the Iron River district, Iron County, Michigan: U. S. Gool. Survey, report in proparation.
Most of the field work, which consisted of mapping of all accessible underground openings and the making of a detalled magnetic survey of the area, was done in 1946 and 1947. Several hundred drill holes have been sunk in the area, and although the core from some has been discarded, that from a relatively large percentage is still avallable. Core from approximately 125,000 feet of drilling was examined in the course of this study.

Despite the volume of data avallable from drilling, underground development, and detalled magnetic surveys, the complex structure of the area makes it quite lmpossible to determine the position of bedrock boundaries with any real degree of accuracy. It is believed that the major features are outlined on the accompanying maps, but it is certain that almost every new drill hole or development will reveal details that will cause some modification in the map pattern.

The work was possible only with the wholehearted cooperation of the mining companies. Complete access was given to the mines and the core storehouses, and to file information. Prints of hundreds of maps and of drill-hole data were made upon request. This assistance and the many other courtesies extended by officials of Plekands, Mather and Co., the M. A. Hanna Co., the ClevelandCliffs Iron Co., the Mineral Mining Co., and the Jones and Laughlin Ore Co., are gratefully acknowledged.

Other members of the U.S. Geological Survey who contributed substantially to this study are Carl E. Dutton, Charles F. Park, Jr., John J. Hill, and Robert B. Hall, and the writers have had the benefit of numerous discussions with F. G. Pardee and G. E. Eddy of the Geological Survey Division of the Michigan Department of Conservation.

\section{THE MAGNETIC SURVEY}

The area was surveyed with vertical magnetometers of the Schmidt type. Most of the survey was made with a temperature-compensated Wolfson instrument (model $\mathrm{M}-1$ ), with a sensitivity that varled from 28.8 to 29.9 gamas 5/ per scale division during the course of the survey. A smaller part was surveyed with a temperature-compensated Askania magnetometer with a sensitivity of 34.5 gammas per scale division. No base-station instrument was used; the diurnal correction curve was obtained by three or four observations at a base-station during the day. The average error is belleved to be about 10 gammas, most of which probably is due to nonlinear diurnal variations and mild magnetic storms that occurred between base-station checks.

5/ A gamma is $1 / 100,000$ of a gauss, which is the fundamental unit of magnotic intensity. The total magnetic field of the earth is about 65,000 gammas in this latitude. The common dip noodlo has a sonsitivity of 300 to 500 Eammas por scalo division. 
For most of the areas, determinations were made at paced intervals of 100 feet a long compass lines 300 feet apart. Each half-mile traverse was tied in to adjacent land boundaries. Approximately 7,000 stations were occupled. The primary base station (zero value) is the sate as that used on the maps of the Ice Lake-Chicagon Creek area (Preliminary map 3-213); it is located on a narrow side road in the $\mathrm{NE}_{\frac{1}{4}} \mathrm{NE} \frac{1}{4} \mathrm{sec} .28$, T. 43 N., R. 34 W., about 30 feet west of the road along the east side of the section. Cultural objects, such as pipe lines, that might affect the determinations were avoided so far as possible, and determinations suspected of being affected were not used in drawing the isomagnetic contaurs. The survey was hampered in the southern part of sec. 24 because of magnetic disturbances set up by the direct current used for tramming in the adjacent mine workings. These disturbances have been noticed more than half a mile away from the nearest workings.

\section{GENERAL GEOLOGY}

The Iron River-Crystal Falls district is a. tightly folded synclinorium which roughly forms a triangular-shaped area, with apices at Iron River, Michigan, Crystal Falls, Michigan, and Florence, Wisconsin (see index map, fig. 1). The bedrock geology of this basin consists of a complexly folded series of slates, graywackes, and iron-formation, which rest on a "greenstone" basement complex comprising pillow lavas, agglomerates, tuffs, some slate, and some iron-formation. The iron-formation and associated rocks within the basin are generally considered to be Upper Huronian, younger than the major ironformation of $t \theta$ Gogebic, Marquette, and old Menominee ranges. The age of the greenstone and associated rocks is in doubt.

The map area covers part of the western apex of the basin. The geology of the southeastern part of the map area (pl. 3) consists, essentialiy, of a fold belt of ironformation bounded successively by older slate and greenstone on the south and southwest, and by younger strata on the north and northeast. However, most of this area of younger rocks contains folds that expose iron-formation at ledge surface; the central part of the synclinorium--that is, the part that contains only the younger rock at ledge surface--lies farther to the east and northeast. The major feature of the northwestern part of the area (pl. I) is the deep synclinal basin in which younger beds that include a magnetic slate are preserved.

The iron-formation and ore in this area are not magnetic, but some of the beds stratigraphically above the iron-formation are strongly so. Much of the geologic interpretation of the area hinges on the pattern of anomalies produced by these magnetic rocks.

Outcrops are very scarce, and in most places the bedrock is mantled by glacial deposits which average about 150 feet thick and locally attain a thickness of more than 300 feet. Both the present surface and the ledge surface are of low to moderate relief.

Except for a few altered diabase dikes, intrusive rocks are unknown in this area.

\section{STRATIGRAPHY}

The stratigraphic succession in adjacent parts of the Iron River-Crystal Falls di.trict has been described in the preliminary reports mentioned above. The stratigraphy of this map area agrees closely with that described in general terms for the Ice Lake-Chlcagon Creek area and, with one important difference, with that described in the report on Mineral

Hills. Continued investigation by the senior author and C. E. Dutton subsequent to the release of the latter report has shown that the concept of a "lower iron-format on", in which the ore of the Bates and east Spies mines was presumed to occur, is not valid, and that the ore on those properties is in the same stratigraphic unit as that elsewhere in the district.

Detalled work in all parts of the district has demonstrated that the stratigr phic succession is reasonably uniform throughout. The almost bewildering repetition of rock types encountered in most places, which led earlier workers to the concept of deltaic conditions of sedimentation with lenticular beds, actually is due to repetition of the same beds on exceedingly tight folds and by faults that are sometimes quite inconspicuous.

In no part of the area can an entirely normal stratigraphic succession be examined. In all places, overt med folds and crossfolds (which also are locally overturned), coupled with $s$ me adjacent faulting and changes in thickness as a result of faulting, shearing, or squeezing, mak $\theta$ determination of the succession extremely difficult. Determination of tops of eds is always a problem; no fossils, of course, are avallable; crossbedding and gradationál bedding are exceedingiy rare; ripple marks are absent. Drag folding is the most useful criterion for the spot determination of tops, but it mast also be used with caution. Use of inadequately exposed drag folds may yleld apparently anomalous results, and in some places the axes of the folds are overturned on cross folds so that an anticline may have the structural form of a steeply plunging syncline, Determination of the stratigraphic succession has thus required much detalled mapping and continual reexamina ion of concepts. However, the stratigraphic succession that has evolved is presented with $c n^{n} 1$ dence, and it is belleved that although future work may add to the detail, the framework will be found correct.

Inasmuch as the great bulk of exploration is natural iy limited so far as possible, to the general zone of 1ron-formation, the stratigraphic succession of that zone is known in much greater detall than that of parts farther removed from the iron-formation. The stratigraphy of the ron-formation and associated rocks is presented in summary form on table 1 , as well as in the following paragraphs. 


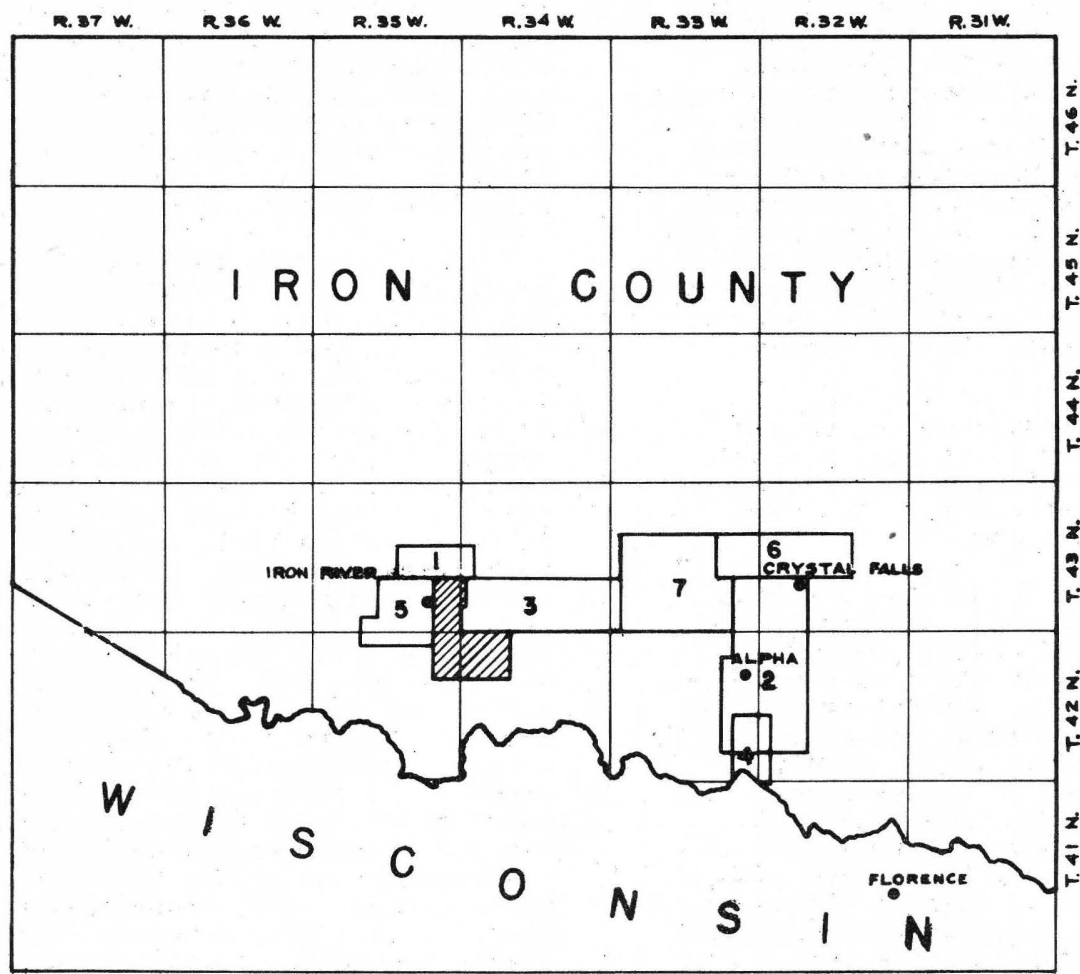

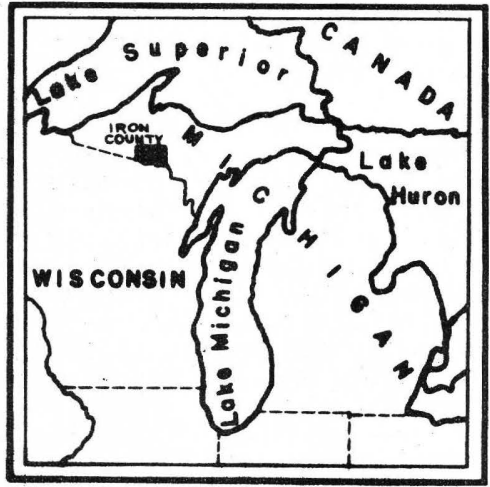

Report in preparation
INDEX MAP OF IRON COUNTY MICHIGAN SHOWING AREAS COVERED BY PRELIMINARY REPORTS

UIA Area covered by this report.

I. Mineral Hills Area.

2 Crystal Falls - Alpho Area.

3 Ice Lake-Chicogon Creek Areo.

4 stoger Aree.

5 Central Iron River Area.

6 Crystal Falls-Paint River Area."

7 Work in erogrese.

Figure 1. 
Greenstone.-The oldest rock in the area 1s greenstone, which makes up the basement on which the younger sedimentary rocks were deposited. The rock is not exposed in the area, but was reportedly cut by two drill holes in the southwestern part of sec. 8 , T. 42 N., R. 34 W. It is exposed several places south of the map area, as in the NW sec. 21, T. 42 N., R. 34 W. Here the greenstone is massive and shows coarse agglomeratic -tructure. Some layers of the greenstone, apparently originaliy tuffacoous, are strongly magnetic. In sec. 18, about $1 \frac{1}{8}$ miles south of the map area, the greenstone contains interbedded slate with some magnetic iron-formation. Greenstone is exposed in the northerm part of sec. 13, T. 42 N., R. 35 W.;. here the rock is diabasic in appearance and is probably intrusive. Pjllow structures are not present in the few outcrops of the basement greenstone near this area, though common enough elsewhere.

The age of the greenstone is, as yet, indeterminate. Whether it is equivalent to volcanics such as the Middle Huronian Hemlock greenstone, or the greenstone of the Keewatin series, is not as yet known.

Footwall strata. - The footwall strata comprise those rocks between the greenstone and the iron-formation. Ilttle or nothing is known within this area of the rock immediately above the greenstone. In the Chicagon Creek area, 6 in sec. 25, T. 43 N., R. 34 W., it is a greenish graywacke, and in the Crystal Falls-Alpha area, 7/ it is a gray-black slate. The oldest footwall rocks in this area for which any description can be given are slates exposed in the NWtiset sec. 12. These rocks are fissile, sericitic to talcose slates in which the cleavage is the dominant structure. The color of the outcropping rock varles from gray to Ilmonitic jellow. The rock is commonif contorted, and bodding is determinable only with difficulty, if at all. Drill holes in

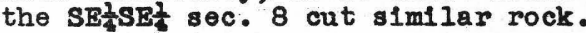

Above the contorted sericitic slate is a series consisting largely of massive fine- to medium-grained gray graywacke and gray sericitic slate. This rock is encountered in many of the deeper drill holes and in some of the mine workings. The shaft stations of the lower levels of the Berkshire mine are in this rock. In the fine-grained facles, cleavage is generally more or less well developed and the rock possesses a distinct nongraphitic sheen not found in any of the younger slates with which it might bo confused. Fine banding is common in the silty layers and these almost invariably show numerous very small faults that are particularly evident in the drill core. The lower part of this series is largeIy fine-grained, banded graywacke. In many places the rock exhlbits an 111-defined, pseudoconglomeratic structure that is due to minor faulting of some layers accompanied by

\footnotetext{
op. cit Jamos, H. L., Clark, L. D., and Smith, L. E.,

7) Pottijohn, F. J., op. cit.
}

chearing and rotation of the faulted fragments. The upper part of the serles, which is commonif entered in mine workings, is largely a dark gray, sericltic, silty slate readily distingulahable from the overlying graphitic slate by its sheen and by its gray, nongraphitic streak. The contact with the graphitic slate is gradational, with sericitic slate alternating with graphitic slate for several feet. As shown by drill core andjoes, the sericitio slate characteristically contains 6 to 8 percent 1 ron, and the graywacke 8 to 12 percent iron, most of which is in the form of interatitial siderite: Oxidation of these rocks, although not common, has been observed were structural conditions were favorable.

overlying the sericitic slates is a graphitic, highly pyritic slate which forms the stratigraphic footwall for the 1ron-formation throughout the Iron River-Crystal Falls district. The bulk of the rock in this area 1s, where unsheared, a thin-bodded to laminat od, dark-gray to black rock with a graphitic streak. Pyrite forms 35 to 50 percent of the rock, but is only rarely visible; for the most part it is indistinguishable from the other fine-grained constituents. Where sheared, the rock is glossy black and parts on innumerable slickensided planes. Near or at the base of the graphitic slate is a characteristic brecc1a 8/ (the "speckled gray" of fleld terminology), which is a marker horlizon throughout the Iron River district. In this area it is rarely more than 10 feet thick and commonly much 1ess. The breccle is rather massive, in contrast to the laminated character of the adjacent slate, and contains mimerous small, angular fragments of slate in a dense, graphitic, pyritic matrix. The fragments, which rarely exceed half an inch in diameter, are most commonly of graphitic slate, though fragments of gray slate are not rare and chert fagments are found occaslonally. In places, many of the graphitic slate fragments show partial or complete replacement by coarse pyrite.

The true thickness of the graphitic slate 18 probably between 20 and 40 feet, although because of folding or squeezing' it may appear to be much thicker or thinner. The iron analyses, as shown in drilling records, are elther high or low, depending upon the method of determination. Quite commoniy the rock is roasted to clear the dark color for titration; as a result, the pyrite is converted to soluble oxide and the records will show an iron content of 15 to 25 percent. If the rook is not roasted, most of the iron remains as insoluble pyrite and the records will show an Iron content of 2 to 6 percent. Considerable confusion has arisen because of this diffort ence in analytical procedure. The graphitio slate, because of 1 ts high pyrite content, Is responsible for the numerous mine fires that have occurred in the district. In specimens and drill core this "burning" of the pyite causes an efflorescence or complote breakdown to whitish powder within a few years.

8/ Dutton, C. E., Park, C. F., Jr., and

Bals løy, J. R., Jr., op. cit. 
Iron-formation-The iron-formation rests on the graphitic slate with an abmupt but conformable contact. The iron-formation, where unoxidized, consists of interlayered dark gray chert and gray siderite with occasional layers of sideritic slate. Graphitic slate partings and seams as much as a few inches thick are not uncommon. The thickness of individual chert and siderite layers may be as much as 4 inches, but more typically range from a quarter of an inch to 2 inches. The siderite and chert are very fine-grained, and layers of one generally contain a small percentage of the other mineral. No iron silicates, such as grunerite, have been found in the unoxidized iron-formation in this area.

Oxidation has converted the siderite to hematite in many places to yield "oxidized iron-formation." The chert that remains is most commonly bleached to white or gray. Leaching of the chert or replacement by iron oxides converts the oxidized iron-formation to ore in which the original banding is generally preserved. The average iron content of the unoxidized iron-formation is approximately 24 percent, that of the ore 50 to 60 percent. Most of the iron-formation is oxidized in part, so that the iron content of the formation as a whole is about 35 percent. On the maps and sections accompanying this report, no distinction is made between oxidized ironformation and ore.

The iron-formation, in almost all places, is tightly folded, so much so that this feature is practically a definitive criterion. Because of this folding, the true thickness of the formation is difficult to determine; in most places it is 100 to 140 feet, but locally it may be as little as 10 feet (see cross section E-E' plate 4) as a result of erosion at the end of iron-formation time.

The top of the iron-formation is, in many places, marked by an unconformity (or disconformity) with the overlying rocks. This unconformity, although widespread in the Iron River-Crystal Falls district,9/ is rarely of sufficient intensity to significantly change the thickness of the iron-formation. Within the iron-formation it is commonly marked by the occurrence, generally in the upper part, of breccias consisting of angular chert fragments and rounded, 1li-defined siderite fragments in a sideritic matrix, the whole retaining the same bulk composition as the bedded iron-formation. In most places, the chert fragments have obviously been transported, but locally the fragments line up as segmented portions of originaliy continuous layers. This rock is believed to be the product of slumping and submarine erosion of the partlyconsolidated, banded sediment as a result of a minor but widespread tectonic distarbance which caused changes of sea-bottom slope.

9/ Pottijohn, F. J., op. cit. op. cit.
Hanging-wall strata.-Because of the unconformity mentioned above, the lower part of the hanging-wall strata is subject to rapid changes in lithology and thickness. The "normal" contact with the iron-formation, though not necessarily the most common, is gradational. At the typical gradational contact, layers of chert, siderite, and sideritic slate alternate with increasingly thicker layers of graywacke until the rock is mostly massive graywacke. Such relations are clearly shown on the loth level of the Buck mine near the west boundary of the NW NE sec. 7. In the area of the east Spies mine (sec. 24), the upper part of the iron-formation is interbedded with layers of massive, nonpyritic black slate. Elsewhere, almost every combination of bedded or brecciated iron-formation with a hanging wall of sideritic slate, silty slate, sideritic graphitic slate, graywacke, graywacke with chert fragments, or sideritic slate with chert fragments can be found. Locally, the rock is graphitic enough to be confused with the footwall graphitic slate, as in the Sples mine area (sec. 24). This rock, however, is sideritic rather than pyritic, as indicated by the soluble iron content. Furthermore, it is most commonly massive rather than laminated, and typicaliy contains scattered chert nodules. As a group, these varieties of hanging-wall strata are characterized by a high iron content (rarely less than 14 percent) and by association with sideritic graywacke that commonly contains chert fragments. The most common type of contact relation, as indicated by examination of the core of many drill holes and examination of exposed contacts, shows bedded or slightly brecciated iron-formation overlain by thin-banded silty sideritic slate which grades within a short distance into graywacke carrying scattered chert fragments.

In some places, notably in the Bengal mine area. Iron-formation breccia grades into sideritic or hematitic graywacke with chert fragments: The two rocks are much alike in appearance, the graywacke being distinguished only by the presence of scattered glassy quartz grains, a more granular texture, and a slightly lower iron content.

Some of the underground holes that were drilled westward from the Caspian mine encountered breccias consisting of chert fragments in a dark, graphitic, sideritic matrix, and there were indications that bedded iron-formation was thin or absent. It seems likely that this indicates erosion of a significant amount of the iron-formation; further, that in some part of the surrounding area the graphitic footwall beds were eroded in the period of disturbance following the deposition of the iron-formation and the material from this footwall rock contributed to the breccia.

The types of the lower hanging-wall strata most commonly encountered in some parts of the map area are listed below:

1. $S \frac{1}{8}$ sec. $24(\mathrm{pl}, 1)$. Massive to bedded, black, sideritic, silty, somewhat graphitic slate overlain by slate or graywacke with or without chert fragments. Commoniy with interbedded layers of siderite and sideritic graywacke. Locally graywacke with chert fragments directly above iron-formation. 
Table 1. Stratigraphle chart summarizing characteristics of the 1ron-formation and associated rocks.

\begin{tabular}{|c|c|c|c|c|c|c|c|}
\hline \multirow[b]{2}{*}{ MAJOR UNIT } & \multirow[b]{2}{*}{ NATURE OF CONTACT } & \multirow[b]{2}{*}{$\begin{array}{l}\text { THFICKNESS } \\
\text { (feet) }\end{array}$} & \multicolumn{2}{|c|}{ SUBDIVISIONS } & \multirow[b]{2}{*}{$\begin{array}{l}\text { IRON CONTENTL/ } \\
\text { (percent) }\end{array}$} & \multirow[b]{2}{*}{ DISTINGUISHING CHARACTERISTICS } & \multirow[b]{2}{*}{ LOGALITIES } \\
\hline & & & Undt & Description & & & \\
\hline \multirow[b]{2}{*}{ MAGNETIC SLATS } & \multirow{3}{*}{$\begin{array}{l}\text { Apparently gradational. } \\
\text { clastic deposits gradu- } \\
\text { ally superseded by chems } \\
\text { cal precipitates. }\end{array}$} & \multirow[b]{2}{*}{$? 100 ?$} & Slaty facles & $\begin{array}{l}\text { Nearly black; composed of very } \\
\text { fine grained micaceous mineral. } \\
\text { Massive, but commonly will break } \\
\text { along parallel cleavage planes. }\end{array}$ & \multirow[b]{2}{*}{$15-25$} & \multirow{2}{*}{$\begin{array}{l}\text { Generally strongly magnetic. In } \\
\text { slaty facies, dark color and finely } \\
\text { micacous habit of predominant min- } \\
\text { eral. In banded facies, hardness } \\
\text { and toughess, fine banding. Maure } \\
\text { color highly characteristic of a } \\
\text { slightly oxldized rock. siump struc- } \\
\text { tures (tiny faults and folds) common } \\
\text { in thin banded types. }\end{array}$} & \multirow{2}{*}{ 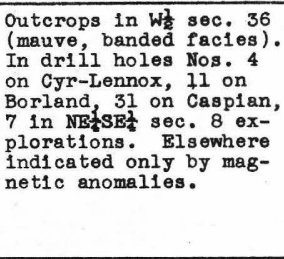 } \\
\hline & & & Banded facies & $\begin{array}{l}\text { Thin-banded to finely laminated, } \\
\text { with lighter and darker layers. } \\
\text { Hard, tough, subconcholal fracture } \\
\text { some layers of 1dentical appear- } \\
\text { ance are nonmagnetic. Color gray, } \\
\text { but rock assumes characteristic } \\
\text { mauve tint where oxidized. }\end{array}$ & & & \\
\hline \multirow{3}{*}{ 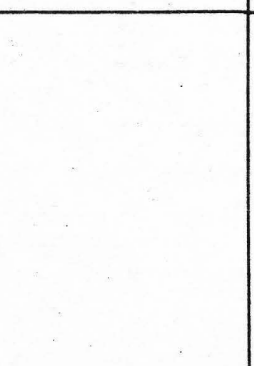 } & & & Gray slate? & Soft, massive, light-colored. & \multirow{7}{*}{$\begin{array}{l}\text { Unoxidized: } \\
114-22 \\
\text { Oxidized: } \\
20-40\end{array}$} & \multirow{7}{*}{ 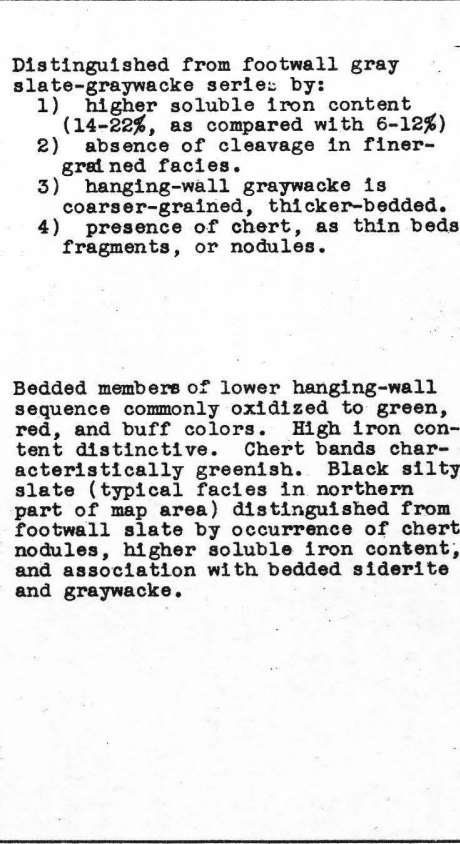 } & \multirow{7}{*}{ Present 1n most mine } \\
\hline & \multirow[t]{2}{*}{ cal prẹcipitates. } & \multirow{6}{*}{$100-400$} & $\begin{array}{l}\text { Massive } \\
\text { graywacke }\end{array}$ & 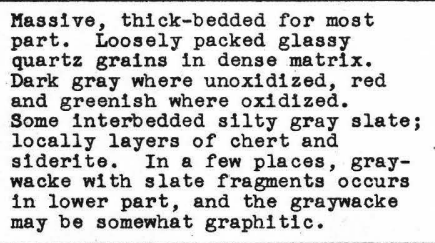 & & & \\
\hline & & & $\begin{array}{l}\text { Graywacke w1 th } \\
\text { chert frag- } \\
\text { ments } 2 \text {. } \\
\end{array}$ & $\begin{array}{l}\text { Massive, gray, coarse graywacke } \\
\text { w1 th angular chert fragments as } \\
\text { much as } 2 \text { inches long. }\end{array}$ & & & \\
\hline \multirow[t]{4}{*}{$\begin{array}{c}\text { HANGING-WALLISTRATA } \\
\text { (GRAYWACE-SLATE } \\
\text { SKRTRS) }\end{array}$} & & & $\begin{array}{l}\text { Slate with } \\
\text { s } \\
\text { o- chert frag- } \\
\text { onds ment }\end{array}$ & $\begin{array}{l}\text { Sideritic slate, locally graph- } \\
\text { 1tic, with anguiar chert frag- } \\
\text { ments. }\end{array}$ & & & \\
\hline & & & \multirow{2}{*}{ 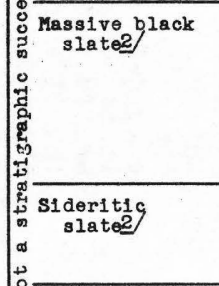 } & $\begin{array}{l}\text { Massive, slightly graphitic. } \\
\text { Individual layers commonly as } \\
\text { much as } 6 \text { 1nches thick. Commonly } \\
\text { with interbeded layers of gray } \\
\text { s1derite or sider1tic graywacke. } \\
\text { In part defintely silty Typi- } \\
\text { caly contains scattered chert } \\
\text { nodules. }\end{array}$ & & & \\
\hline & & & & $\begin{array}{l}\text { Thin-banded, particularly evi- } \\
\text { dent where oxidized. Color gray } \\
\text { where unoxidized, green and } \\
\text { reddish where oxidized. }\end{array}$ & & & \\
\hline & & & Fine-grained & $\begin{array}{l}\text { S1milar to above but thicker- } \\
\text { bedded and coarser-grained. } \\
\text { Usually found with gradational, } \\
\text { 1nterbedded contact w1th bedded } \\
\text { 1ron-formation. }\end{array}$ & & & \\
\hline
\end{tabular}

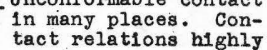




\begin{tabular}{|c|c|c|c|c|c|c|c|}
\hline \multirow[b]{2}{*}{ IROM-PORMATIOI } & \multirow[t]{2}{*}{ 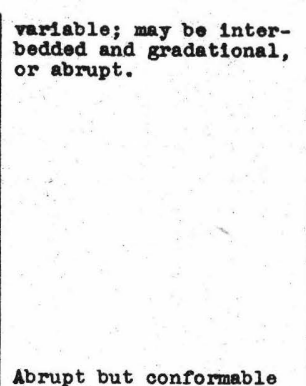 } & \multirow[b]{2}{*}{140} & $\left|\begin{array}{l}\text { Iron-formation } \\
\text { brococeder } \\
\text { not orery- } \\
\text { ninere present) }\end{array}\right|$ & 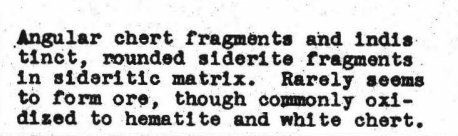 & \multirow{2}{*}{ 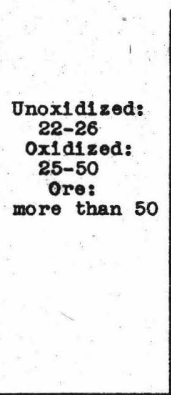 } & \multirow{2}{*}{ 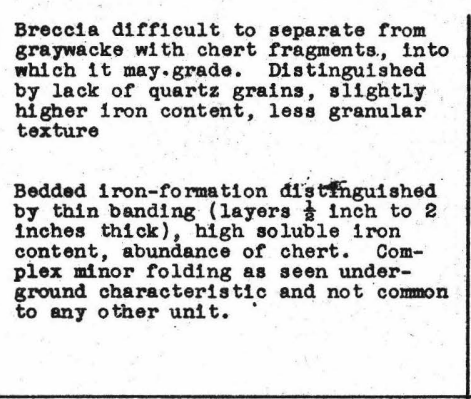 } & \multirow[b]{2}{*}{ All mine morkings. } \\
\hline & & & $\mid \begin{array}{c}\text { Beddade } 1 \text { r ron- } \\
\text { format tion }\end{array}$ & 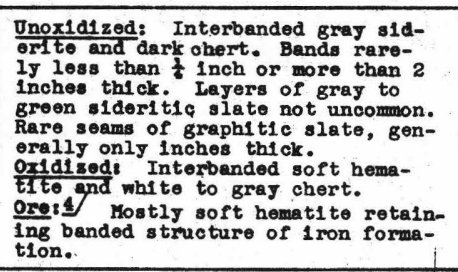 & & & \\
\hline \multirow{2}{*}{ ORAPHITIC SLATE } & \multirow{2}{*}{ 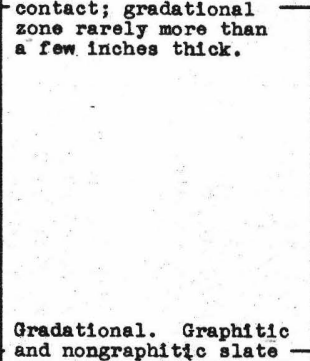 } & \multirow{2}{*}{$20-40$} & $\begin{array}{c}\text { Lamnated } \\
\text { graphit t10 slate }\end{array}$ & 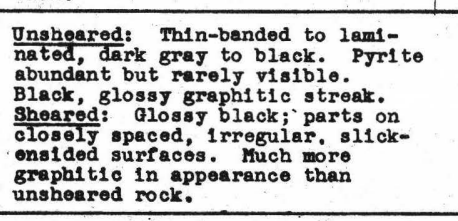 & \multirow[t]{2}{*}{ 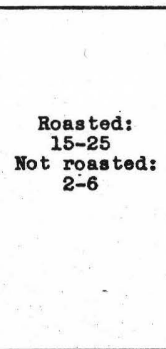 } & 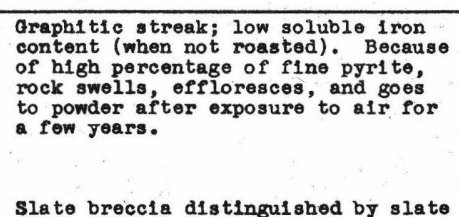 & \multirow{2}{*}{$\underset{\text { Porkings }}{\text { Present }}$} \\
\hline & & & 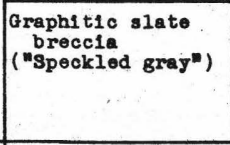 & 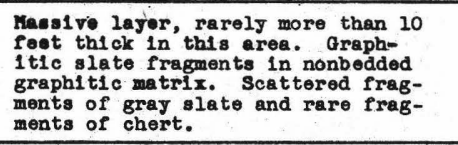 & & 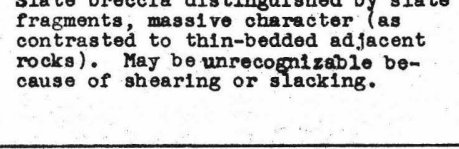 & \\
\hline $\begin{array}{l}\text { SERTCITIC GRAY } \\
\text { SLATR-GRAWWACKB } \\
\text { SBRTRS }\end{array}$ & 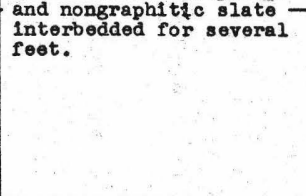 & Unknom & 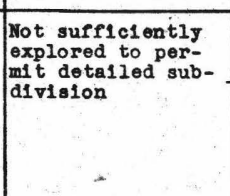 & 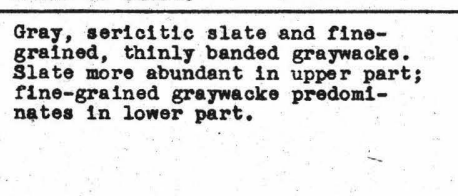 & $\begin{array}{l}\text { Slate: } \\
\text { 6-10 } \\
\text { araphacke } \\
\text { a-12 }\end{array}$ & 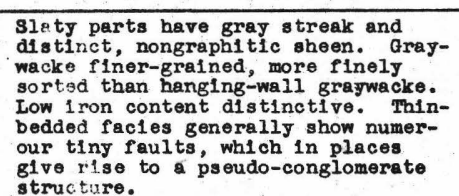 & 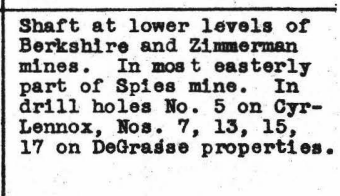 \\
\hline
\end{tabular}

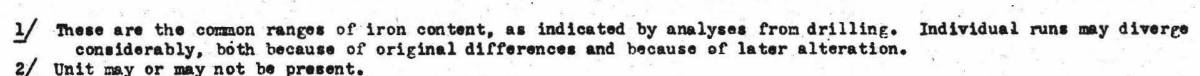

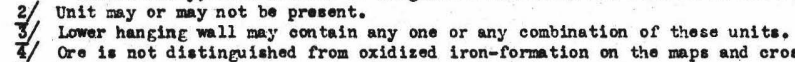


2. Cyr-Lennox area (SW sec. 36, pl. 1). Silty, gray to green, sideritic slate overlain by graywacke with or without chert fragments.

3. Barras area (SW NEt sec. $36, \mathrm{pl}, 1$ ). Graywacke or silty gray, green or red slate. Deeply oxidized.

4. Bengal mine area (SEt sec. 36, pl. 1). Graywacke with chert fragments; deeply oxidized.

5. Tully mine area (SEt sec. 36, pl, 1). Probably oxldized graywack $\theta$.

6. Caspian mine area (sec. 1, pl. 3). (a) West, breccla of chert fragments in a dark, sideritic, somewhat graphitic matrix. (b) East, silty red to green slate with scattered chert fragments.

7. Nl Borland area. (NW sec. 6, pl, 3). Graywacke with chert fragments.

8. Corry area ( $\mathrm{NE}_{\frac{1}{4}} \mathrm{SW} \frac{1}{4}$ sec. $\left.6, \mathrm{pl}, 3\right)$. Graywacke and silty slate. Locally with chert fragments.

9. Buck mine area (SW 3). Mostly massive graywacke, locally graywacke with chert fragments.

10. Zimmerman mine area (NWt sec. 7, pl. 3). Graywacke. Locally some interbedded graphitic slate.

11. DeGrasse area ( $\mathrm{NE}^{2}$ sec. 7, pl. 3). Graywacke, commonly interbedded with some black graphitic slate.

12. Section 8 (pi. 3). Graywacke with some silty slate.

All the above-described rock types grade upward into massive fine- to coarse-grained graywacke which includes some slity gray slate and, not uncommonly, thin layers of chert and siderite. The hanging-wall graywácke and slate are marked by a high content of siderite, so that the unaltered rock has an average iron content of 16 to 18 percent, as compared with an average iron content of 6 to 12 percent in the footwall gray slate and graywacke. In the graywacke, the siderite forms a matrix for poorly rounded, glassy quartz grains. The slates are sideritic and gray, except locally where graphitic; cleavage, such as that in the sootwall sericitic gray slate, is not present.

In some parts of the area, graywacke with fragments of black slate occurs above the graywacke with chert fragments. The frag ments, as mach as half an inch long, are rather angular, and of simtlar lithology to the footwall slates. The matrix in such rock is commonly slightly graphitic, and the soluble iron content lower than normal. The rock is readily distinguished from the footwall slate breccla by the lighter color of the matrix, more massive character, greater hardness, and essentially non-pyritic character.

The thickness of the hanging-wall graywacke series appears to be highly variable; in places, it may possibly attain a true thickness of several hundred feet, but more commonly the true thickness appears to be on the order of 200 feet.

In most places adjacent to oxidized 1ronformation or ore, the hanging-wall strata are altered to ferruginous rocks in which red and green colors predominate. Much of the rock is irregularly mottled, with the green portions apparently beling altered to hematitic ped. The green coloration is due to a very finegrained chlorite that has replaced part or all of the original siderite, and the red colora- tion is due to later alteration or replacement of the chlorite and remaining siderite to red earthy hematite. In many places, this alteration brings out a fine banding in the silty slates that in the unoxidized rock is not particularly evident. Alteration to clay minerals, as yet unidentified, occurs locally, but in general probably is rare.

Magnetic slate.-Above the graywacke and gray-slate hanging-wall series is a magnetic slate that is the youngest rock in this area for which description can be given. This unit, which is one of the most distinctive sedimentary units in the Iron River-Crystal Falls district, is composed of at least two distinct rock types.

The lower member, above the graywacke, is a gray, thinly-banded, sideritic rock of cherty appearance in which layers containing disseminated, finely crystalline magnetite occur. Some parts of this rock, however, contain ilttle or no magnetite. The rock is hard and tough and breaks with an almost conchoidal fracture, and the finely banded varieties show, in places, contorted or minutely faulted structures that probably are due to slumping prior to consolidation. Where slightly oxidized, as in outcrops, the rock assumes a highly distinctive mauve or purple color. Above the banded gray rock is a rather massive, dark, strongly magnetic rock. It is composed largeiy of a very fine mica or chlorite-like mineral which may be stilpnomelane (an iron-rich silicate), with abundant tiny crystals of magnetite scattered throughout.

The magnetic slate (mauve-colored, banded facies) is exposed in several places on the hill on which the town of stambaugh is built, and magnetic slate has been cut by several drill holes. Drill hole No. 14 (the most northwesterly hole in the NEtsW sec. 36, pl. 1) on the Cyr-Lennox property entered magnetic slate after passing through graywacke (apparently overturned); drill hole Borland No. 11 in the NEl NWt sec. 6. (pl. 3) entered the magnetic slate at ledge surface and cut an excellent section before entering graywacke; drill hole No. 31 on the Caspian property (sec. 1 , pl. 3) entered a few feet of magnetic slate after passing through iron-formation and some slate, as shown on cross section C-C' (pl. 4); and drill bole No. 7 in the NEtSEt sec. 8 (pl. 3) cut the magnetic slate at ledge surface.

The iron content of the magnetic slate varies from 15 to 25 percent (average about 19 percent), the iron being in the form of magnotite, siderite, or soluble silicate (possibly stlipnomelane). Because of this, and because of the banded cherty character of some facies, the magnetic slate sometimes bas been mistaken for unoxidiżod iron-formation. The thickness of the magnetic slate in this area is not known; in the Crystal Falls area 10/, It is about 100 feet.

10) Pottijohn, F. J., op. cit. 
The magnetic slate presents many aspects not clearly understood. Many problems, such as the character of the orlginal sediment and the orlgin of the stilpnomelane and magnetite, await further study.

\section{STRUCTURE}

structurally, the map area forms part of the tightly-folded western apex of the Iron River-Crystal Falls basin. There is, however, no proof that the basin is completely closed off in the Iron River area. It is possible that this "apex" is only a constricted part of a basin which continues to the west. The dominant trend of the folds varles from nearly east-west in the southeastern part of the area to nearly north-south in the northwest, but almost everywhere cross folds, at neariy right angles to the major trend, are present. Overturning, both of folds and cross folds, is general. The direction of overturn is not consistent even in vertical section, although most of the cross folds are overturned to the south and east. Because of these complexities, It is virtualig impossible to deplet adequately the structure by means of two-dimensional maps and sections. A vertical section, arb1trarily chosen as to position, may completely fail to 1llustrate the structure. The section may cut some of the folds in positions where their axes are overturned on cross folds; so that an anticline may show as an isolated lens of footwall strata completely surrounded by iron-formation, or a syncline may show only a an 1solated mass of hanging-wall strata surrounded by iron-formation. The sections shown on plate 4 were chosen, so far as possible, to 1llustrate the major structures without complications such as described above, and, as a result, are mach simpler than the majority of sections drawn.

The origin of the cross folds is a matter for some confecture. The fact that the cross folds normaliy maintain an orientation approximately at right angles to the dominant trend would appear to indicate some genetic relation between the two sets. Also, the cross folds do not have the persistence of strike that might be expected of structures which were developed in a period of deformation later than that which produced the dominant set. is therefore tentatively concluded that both folds and cross folds were formed at approxim. mately the same time-at least during the same period of deformation.

Faults are common, and many have large apparent throws. Most appear to have developed elther as attenuation of folds or as adjustments to release stresses set up by folds, The faults are generally tight; commonly they are marked by veln quartz, or by squeezed graphltic slate, or by both. Most appear to form impermeable barriers rather than channels for movement of solutions.

The structure of individual areas is discussed under "Summary descriptions:"

\section{ORE DEPOSITS}

The ore deposits are composed malnly of soft red hematite, with subordinate hard, fine-grained hematite ("blue oren) and limonite (goethite). The latter may be very hard and compact, or earthy. For the most part the ore bodies retain the stmucture of the original bedded chert-siderite rock, although where replacement has been nearly complete, the structure may be hard to discerm. Only locally does the ore show crushing or other evidence of slump. The ore tends to be porous and vuggy and is always a water-bearer. The ore in the ground is generally calculated on the basis of 12 cublc feet to the ton, whereas a hematite ore assaying 55 percent iron, if solld, should contain about 8 cublc feet to the ton (assuming a specific gravity of 5.0 for the hematite and 3.0 for the waste mater1al). Although the ore bodies are rather pegular in plan and section, the ore boundaHes are, of course, gradational.

The structural control of the ore is in most places obvious. The ore commonly, but by no means always, 11 es directly on the footwall of graphitic slate along the keel of a syncline. In this structural position, mach of the iron-formation may be converted to ore, and ore may be present on minor anticlinal. structures within the larger synclines. The ore bodles are more irregular and generally smaller on the limbs of an ore-bearing structure. The ore, if present, occurs on the structural footwall (as distinct from the stratigraphle footwall), so that on the overturned limb of an overturned fold the ore will bo in the upper part (stratigraphically) of the iron-formation and rest on a structural footwall of hanging-wall stwata. In some cross sections, an ore body may appear to lack structural control. Phis 18 usualiy only an apparent lack as an examination of the maps generally will reveal that the controling structure is a cross fold, and that the structural footwall of the ore is sub-parallel to, and outside of, the plane of section.

The effect of cross folding of a syncline on the localization of ore is very pronounced in some places, the "lows" of a syncline-that is, the intersection of the major syncline with a cross syncline-being much more favorable than the "highs" of the same syncline at its intersection with cross anticine.

The effect of strongly overturned footwall trata that forms an "overhang" above $a$ syncline of iron-formation is to inhibit oxidation, although, if the plunge of the fold is very steep, oxidation to ore may occur along the fold axis despite the overhang of impermeable footwall slate. The latter conditions prevall at the Fogarty property in sec. I (see cross section E-E', pl. 4).

There has been no indication thus far in the Iron River district of the depth to which ore bodies might extend. Within the area discussed in this report, the deepest mine is the Buck, from which ore is mined at depths of about 1,000 feet below the surface. However, $a$ short distance west of the map area, ore is being mined from the Hlawatha mine more than 2,000 feet below the surface. Many ore bodies do, of course, bottom at lesser depths, but in ali of the mines thus far examined, the control is structural. 
An important difference ex st between ore bodies formed on a structural footwall of hanging-wall strata from tho e formed in normal position on footwall strata. Ore bodies resting on overturned stratigraphic hangingwall strata will "tall" out with depth into oxidized iron-formation, inasmuch as the infolded hanging-wall strata must, of necessity, steepen with depth and then assume the normal spatial relation as a stmactural hanging wall to the iron-formation. In contrast, ore bodies on a structural (and stratigraphic) footwall of graphitic slate will normaliy continue, with some breaks because of structural irregularities, down to the keel of the syncline and will not end until the bottom of the fold is reached. Some of these relations are illustrated in cross section D-D' (pl. 4), which although it does not show ore, shows stoped areas. It will be noted that the ore (as indicated by stopes) that rested on the overturned hanging-wall graywack $\theta$ bottomed in iron-formation, and that a gap existed between the "hanging-wall ore" and the "footwall ore."

of considerable interest, but apparently of little or no importance so far as the formation of the ore is concerned, is evidence which points to an epoch of mild hydrothermal activity after the ore was formed. In both oxidized and unoxldized iron-formation (and in other rocks), veinlets and crystal-lined vugs occur which contain abundant small, bright crystals of chalcopyrite, specularite, pyrite, marcasite, barite, chlorite, calcite, quartz, and apatite (the latter found in only one specimen). The vugs characteristicaliy develop in the chert layers, and in one place were found developed in the chert fragments of compact, unsheared, oxidized iron-formation breccia. Had the oxidation that produced the hematite in the matrix of the breccia been later than the development and filling of the vugs, the delicate crystals, particularly those of chalcopyrite, certainly would have been either destroyed or altered.

The nature of the ore-forming process, particularly as to whether the solutions were of surface (meteoric) or deep-seated (hydrothermal) origin is a controversial point which cannot be discussed adequately here. However, in all places where sufficient data are avali$a b l e$, it is clear that the ore is related to a structural footwall, and the writers see no evidence to warrant serlous divergence from the concept, postulated fifty years ago, that the major factor has been the presence of meteoric waters that worked from the surface downward along the iron-formation, although divergence of thought exists as to the nature of the system and the reactions.

Some factors that should ba considered in the search for ore are summarized below. It must be recognized, however, that these are tentative generalizations, and exceptions can be found.

1. Because of the complex structure of the area, in particular the widespread overtuming of beds, the majority of deep holes drilled within the general belt of ironformation folds will encounter iron-formation regardless of what rock is encountered at ledge. This is strikingly broug out by the fact that almost every mine shaft in the Iron River district has entered iron-formation despite all attempts to avold just such a con- tingency.

2. Extensive lteration of the hangingwall graywacke and slate is common in the vicinity of the. larger ore bodies in the ironformation. In this altered zone, the rocks are commonly light green, reddish, or buff, as a result of chloritization and hematization. Such alteration of the graywacke should be considered a favorable indication and the nearby iron-formation should be well explored.

3. The larger ore bodies are most commonIy to $\mathrm{b} \theta$ found along the keel of a synclinal structure, which is either open (that is, not overturned) or only moderately overturned so that the footwall beds of the adjacent ant1cline do not "overhang" the keel. However, if the folds have steep plunges, ore may be found even where the keel is overhung by the footwall slate.

4. The "lows" of a syncline-that is, its intersection with cross synclines-are the most favorable locations for ore. Such cross folas may be located by detailed mapping of the plunges of minor folds in the area, or by their effect on adjacen' parallel syncilnes which have been explored, or by alinement of magnetic anomalies.

5. Ore bodies that occur on the limbs of a syncilne are generally more irregularly distributed and smaller than those on the keel of the syncline.

6. On the overturned limb of an overturned syncline, the ore (1f present) will be found in the upper part of the formation resting on the structural footwall of hanging-wall rocks. Such ore bodies will not contimue downward to merge with keel ore bodies, but will bottom in oxidized iron-formation. Ore bodles on the normal limb will occur in the lower part of the iron-formation resting on the stratigraphic and structural footwall, and may be continuous into the keel ore bodies. Converse$1 y$, the position of ore may be used to determine whether the limb of a syncline is normal or overturned. For example, if a horizontal drill hole successively cuts hanging-wall graywacke, ore, oxidized iron-formation, and footwall slate, the limb may be assumed to be overturned; if it successively cuts graywacke, oxidized iron-formation, ore, and footwall slate, the limb may be assumed to be normal.

\section{INTERPRETATION OF THE MAGNETIC DATA}

The zero magnetic value on the magnetic maps (pls. 1,2 ) has approximately the value of the normal magnetic field of the earth in this latitude. Any appreciablo deviation from this value may be considered to be due to an unusual magnetic property of the underlying rock. This deviation is termed a magnetic anomaly, and is expressed in magnetic units (gammas) above or below the zero value. The general concepts of interpretation of the magnetic data are similar to those expressed for the adjacent Ice Lake-Chicagon Creek area, and the following excerpt is taken from that reportill

\footnotetext{
11/ Janes, H. L., Clark, L D., and Smith, L. E., op. cit., pp. 6-7.
} 
"The largest and most persistent anomalles are recorded over the magnetic siate, but broad areas of weak anomaly are recorded over the hanging-wall beds stratigraphically below the strongly magnetic horizon. * * * Geologic interpretation of the anomalies has been prefaced on the assumptions listed below:

1. The major anomalles are produced by the magnetic slate.

2. The magnetic slate is only rarely nonmagnetic, although the intensity of the anomaly it produces varies within wide limits.

3. The hanging-wall beds below the magnetic slate are weakly and rather uniformly magnetic and, if present in sufficient volume, give rise to measurable magnetic anomalies.

4. The rock magnetism is predominantly of the induced type (that is, produced by and parallel to the earth's present magnetic field), and residual magnetism (polarization) is relatively subordinate. This assumption is based on tests with specimens on field instruments, and on the general pattern of the magnetic values. It is further assumed that, because of the steep dips of the formations and the high angle of magnetic inclination $\left(76^{\circ}\right)$ in this latitude, the negative (lower) pole of most of the anomalous bodies has no apprec1able effect at the surface."

Some special problems have arisen in the interpretation of this survey that were not present (or at least not considered important) in the interpretation of the Ice Lake-Chicagon Creek survey. The fact that the southeastern part of this map area (pl. 2) is adjacent to the greenstone basement which apparently dips beneath the younger rocks gives rise to one major point of difference between the two areas. Inasmuch as the greenstone is in part strongly magnetic and is not at a uniform depth, the magnetic "datum" changes from place to place; the observed magnetic value at any point is thus the sum of two components, one of which is due to the deep-seated basement rock, and one of which is due to the immediately underlying rock. In secs. 7,8 , and 9 (pl. 2) a consistent, gradual rise is noted toward the south, and exploratory traverses beyond the map area show that the values gradually increase until the high anomaly of the strongly magnetic part of the greenstone is reached. Further, in sec. 8, very considerable differences of value are obtained along the strike of the same beds with no indication that the difference is due to change in the immediately underlying rocks. This gradual increase toward the east is attributed to a change in character of the basement rock. In other places, notably in the north half of the area shown on pl..1, the magnetic datum appears to be lower than normal and most values on the map are negative.
Because of this complicating factor of a variable magnetic base level. the gamma value of the magnetic determination in many parts of the area holds little signiflcance, and, as a result, the specific magnetic contours cannot be assumed to be subparaliel to geologic boundaries (as was assumed in parts of the adjacent Ice Lake-Chicagon Creek area). Attempts have been made to separate graphically the basement anomaly from that of the sedimentary rocks above, but these have been only partly successful. However, the problem appears to be a serious one only in the southeastern part of this area. Another difference between the two areas is that in at le ast one place (Stambaugh Hill, in sec. 36, pl. 1) the magnetic slate is polarized, as shown by the variabillty of values on the map, and by fleld tests with specimens.

Aside from the problems discussed above, interpretation of the magnetic data has been similar to that in the report on the Ice LakeChicagon Creek area, from which this second excerpt is taken: 12j

"Interpretation of bedrock structure from the patterm of the magnetic data divides into two general classes:

1. The magnetic anomaly is directly over the ledge outcrop of a bed of magnetic rock; as such, the crest line of the anomaly forms a map pattern similar to that of the bed and will so outline the structure. The anomaly is normally narrow, with a steep gradient.

2. The magnetic anomaly is over a tight fold of magnetic strata which does not contain higher nonmagnetic beds. In this case, a single crest line follows approximately the axis of the fold. The trend of any particular bed will parallel the crest line of the anomaly only along the flanks of the structure; on the nose of the structure this trend is subparallel to the magnetic contours, and, at the axial line, the trend of the bed will be at right angles to the crest line of the anomaly.

Inasmuch as cross-folding is extremely common in this area, many of the synclines are spoon-shaped and isolated because of reversals of plunge. If the 1solated 'spoon' contains tightly folded magnetic beds and is covered with an appreciable thickness of drift-so that closely spaced anomalies will merge-there will be a single crest line which will have a maximum intensity over the deepest part of the trough, and which will decrease to zero in both directions along the axis. The anomaly is normally broad, with a relatively low gradi-. ent. If the syncine is not isolated and widens so as to include nonmagnetic beds above the magnetic slate, the anomaly will separate into two parts. ** *

12/ James, H. L., Clark, L. D., and Smith, L. E., op. cit., pp. 7-8. 
Overtumed structures are not uncommon

he area, and these give rise to modifications of the magnetic pattern outlined above. In general, the crest of an anomaly above an overturned syncline contalning magnetic beds is displaced away from the axis of the syncline toward the overturned limb of the structure."

As in much of the Ice Lake-Chicagon Creek area, most of the larger anomalies in this map area are interpreted as being located over tight synclines of magnetic slate, so that the crest line of the anomaly and the axis of the syncline roughly coincide.

The chief value of the magnetic survey, aside from the location of areas of magnetic slate, is in providing a "carry-over" from one area of physical exploration to another in the complete absence of outcrops. Wi thout this independent evidence, it would be quite impossible to draw even tentative geologic boundaries between anything except cioselyspaced explorations. In addition, the magnetic survey helps in delineating the hangingwall graywacke series; this is clearly shown by the broad area of low magnetic anomaly in sec. 6 (p1. 2) where drilling indicates that hanging-wall graywacke and allied rocks form most of the ledge surface. However, in parts of secs. 24, 25, and 36,(pl. 1), most drill holes have encountered hanglng-wall graywacke, yet magnetic values are low. These apparent exceptions to the generalization that the hanging-wall graywacke series causes low but appreciable magnetic anomalles are not entirely understood. Locally, as in the $\mathrm{SE} \frac{1}{4} \mathrm{sec} .36$ (pl. 1), it may be due to oxidation; elsewhere the reason is not known, although it may be that because of tight folding with the ironformation and footwall slates there is insufficient volume of the graywackes to cause appreciable anomaly.

\section{SUMMARY DESCRIPTIONS}

W

All of the exploration in that part of sec. 19 included in this report is within the NW $\frac{1}{4}$ SW $\frac{1}{4}$. This tract is entered by the most easterly workings of the fourth level of the Spies mine, and has been explored by several underground holes from that level. The 23 surface holes that have been sunk in the area represent three separate explorations, one by the M. A. Hanna Co., one by the Carpenter interests, and one (the most recent) by the cleveland-Cliff's Iron Co. Only the core from the latter exploration, which was limited to the western part of the "forty", was avallable for examination.

The major structural trend in the NW is a little east of north, and the dominant structur $\theta$ is the broad anticline, illustrated in cross section ${\mathrm{A}-\mathrm{A}^{\prime}}^{\prime}(\mathrm{pl}$. 4), that is entered by the workings of the fourth level Spies mine and deflned by several underground holes that were drliled easterly to the east flank of the structure. This drilling also indicates that an anticlinal crosswarp centers approximately along the line of cross section, so that minor folds plunge both north and south from this axis. The inferred fault shown on the map (pl. 1) is based on drill-hole evidence. Other faults are almost certainly present but cannot be defined on the basis of present data.
None of the core from the surface drill holes in the central and eastern parts of the "forty" has been preserved, so that classification of the eas.tern part as "hanging-wal 1 strata" is open to considerable doubt.

The SW Magnetic values are low and it seems likely that iron-formation will be exposed at ledge in part, if not most, of the area.

W $\frac{1}{2} W^{\frac{1}{2}}$ section 30, T. 43 N., R. 34 W., plate I

No direct evidence concerning bedrock is available for the part of sec. 30 shown on the map, and very little evidence is available for adjoining areas. The definite anomaly in the SW NW $W^{\frac{1}{4}}$ indicates a fairly extensive synclinal basin of hanging-wall rocks in that area. The trend is nearly east-west, although in the adjacent area to the east, 13 this same anomaly shows a trend that is nearly north-south.

The low magnetic values in the vicinity of Ice Lake indicate that iron-formation or footwall strata may form much of the ledge surface in that area.

S $\frac{1}{2}$ section 24 , T. 43 N., R. 35 W., plate 1

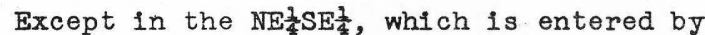
the workings of the spies mine and explored in connection with that operation, the information in the south half of sec. 24 is too meager and scattered to permit anything except tentative conclusions. Magnetic values are generally low throughout the area, although weak positive anomalies are present in the $W_{2}^{\frac{1}{2}} S W_{\frac{3}{4}}$ and in the $N \frac{1}{2} S E \frac{1}{4}$. The magnetic survey was hampered in the northerm part of the area by magnetic disturbances arising from the adjacent spies mine. However, the values shown in that area may be considered reliable, as the stations were occupled on a day when the power was shut off at the mine.

Spies mine area ( $\left.\frac{1}{2} S S^{\frac{1}{4}}\right)$. - The structural trends in the east spies mine are nearly northsouth. The fold axes are steeply pitching, so that in vertical section the folds have an appearance of tightness that is more apparent than real (see cross section $\mathrm{A}-\mathrm{A}^{\prime}$, pl. 4 ). The iron-formation encountered in the fourth level is bounded on the east by a nearly vertical fault that has cut out most of the footwall graphitic slate, so that the iron-formation is in contact with the footwall gray slate and graywacke. This fault is shown on the cross section referred to above.

The hanging-wall strata in the Ex sec. 24 are significantly different from those found elsewhere in the map area Here the hangingwall succession commonly includes layers of massive, black, slightly graphitic slate, which typically contains scattered chert nodules. The rock superficially resembles footwall graphitic slate, from which it is distinguished by its nonpyritic character, thicker bedding, chert nodules, and higher soluble iron content.

13/ James, H. L., Clark, L. D., and Smith, L. E., op. cit. 
The two drill holes near the center of the SE $\frac{1}{4}$ both entered hanging-wall graywacke or slate at ledge surface, but the more southerly hole (a steep angle hole to the south) was continued until it entered oxidized ironformation. Low magnetic vaiues were obtained over the area of known hanging-wall rock, as shown on plate 2. As discussed under "Interpretation of magnetic data", such low values may be attributed in part to a change in character of the deep-seated basement rock so that the local magnetic datum is lower than normal. However, it is possible that the strata are so folded with iron-formation and footwall rocks that the hanging-wall rock is not present in sufficient volume to cause an appreciable anomaly.

SW $\frac{1}{4}$ sec. 24. The information in this area is too scant to determine structural trends, although the weak positive anomaly in the western part suggests trends more nearly east-west than north-south. The anomaly presumably indicated a fairly deep synclinal basin of hanging-wall strata. The inferred ha.rging-wall strata would be separated by a belt of iron-formation from the footwall area in the workings and exploration of the SpiesVirgil mine to the north.

The five drill holes on the Carlson exploration in the NEtSW show oxidized ironformation in the southern part bounded on the north by hanging-wall graywacke and slate.

Section 25, T. 43 N., R. 35 W., plate 1

Except for the W $\frac{1}{2} S W \frac{1}{4}$, which is to be described as part of a separate report, there has been very little exploration in the $W^{\frac{1}{2}}$ sec. 25, and none whatsoever in the east half. The magnetic survey reveals little. The weak positive anomalies in the east part of the south half of the section probably are due to hanging-wall strata, though no direct information is available.

Five deep holes were drilled in the SW $\frac{1}{4}$ NW $\frac{1}{4}$. The core was not avallable for examination, but company records show that all the holes entered graywacke or slate at ledge and continued until oxidized iron-formation was reached. Magnetic values are low despite the drill-hole evidence that the ledge surface is predominantly hanging-wall graywacke and slate. The low level of magnetic values in part may be due to changes in the basement rock. However, other factors, such as oxidation, or folding so that the hanging-wall graywacke is not present in sufficient volume to cause appreciable anomaly, may be important.

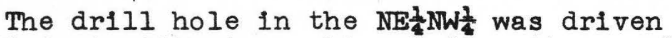
to 299 feet without reaching ledge; it reveals the existence of a remarkably deep trough in the ledge surface in that area.

Section 36, T. 43 N., R. 35 W., plate I

The most prominent structural feature in sec. 36 is the major syncline of magnetic slate that forms the hill on which the town of stambaugh is built. This structure, which doubtless contains numerous minor anticlines and synclines, trends a little west of rorth. The magnetic slate (cherty, mauve facies) is exposed in low, glacially pollshed outcrops in the immediate vicinity of Stambaugh High School (in the SW $\frac{1}{4} N W^{\frac{1}{4}}$ ), and in outcrops along the east side of NW $\frac{1}{4} S W \frac{3}{4}$. Observed dips are nearly vertical. The magnetic values over the slate are high and variable, and some of the rock is strongly polarized even in hand spec1men. A second, much shallower syncline of magnetic slate is indicated by the magnetic anomaly in the NEt of the section; it trends nearly east and west. Other parts of sec. 36 are discussed below.

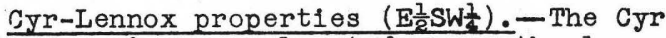
and Iennox mines are located on northerly trending structures which are essentially drag folds on the east flank of the Stambaugh Hill syncline. An anticlinal buckle of footwall is cut by some of the workings and by drill hole No. 5; it is separated by a shallow syncline from another footwall area on the east, as shown in cross section $\mathrm{B}^{\prime} \mathrm{B}^{\prime}(\mathrm{pl}$. 4). The drill holes along the west side of the NEt SW and $\mathrm{SE}_{\frac{1}{4}} \mathrm{SW} \frac{1}{4}$ all entered han ging-wall graywacke and slate at ledge, but hole No. 14 (the most

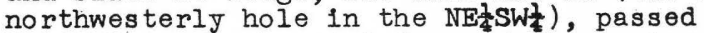
through graywacke at ledge and then entered an overturned syncline of magnetic slate. Easterly trending cross-folds are evident from the geologic pattern in the underground workings, particularly in the southern part of the Lennox property.

Barras property ( $\left.\frac{1}{2} \mathrm{NE}^{\frac{1}{4}}\right)$. - The Barras mine appears to have been developed in iron-formation that oc curs on northwesterly trending anticlinal folds with hanging-wall slate and graywacke. Core was avaliable from all the surface drill holes; all entered deeply oxidized lower hanging-wall slate or graywacke at ledge surface.

Bengal-Tully area (SEt).-The detalls of the geology of this area remain unsolved. In a broad sense, most of the area is anticlinal, so far as the iron-formation is concerned, with iron-formation and hanging-wall strata forming most of the ledge surface. Most of the rock, including the hanging-wall strata, is so deeply oxidized that lithologic identification is difficult, and, in the case of the Tully surface drilling, for which only analyses were available, definite separation of the iron-formation and hanging-wall strata is nearly impossible.

Very little footwall rock has been entered by either the mine workings or the drill holes. Most of the extensive drilling from the lower levels of the Bengal mine cut a complex of oxidized iron-formation and oxidized hanging-wall graywacke with abundant chert breccia, although underground holes Nos. 22,25 , and 26 ( 211 deep holes drilled in a general southerly direction at steep angles) entered the footwall rock.

The location of the ore in contact with hanging-wali strata, the extensive oxidation of the latter, the obvious broad-scale anticlinal structure of the area, and the tailingout of ore bodies into oxidized iron-formation with depth strongly indicate that much of the ore of the Bengal and Tully properties occurs on the overturned limbs and axes of a series of overturned anticlinal folds. The structure is complicated by overturned cross-folds, 
which coupled with the difficulty in making Iithologic identifications because of the deop oxicition, make structural delineation and the diawing of rational cross sections almost impossible. Though it has not been found possible thus far to draw an illustrative cross section, the typical ore body now known in the area is believed to occur in an anticline of iron-formation, the axis of which is overtumed slightly past vertical so that the structural form is that of a steeply-plunging syncline. Such an ore body may be expected to end in oxidized iron-formation when the pitch of the fold becomes $90^{\circ}$ or less.

Section 1, T. 42 N., R. 35 W., plate 3

The northerm and eastern parts of sec. 1 are marked by projections of hanging-wall strata from the extensive areas of younger rock to the northwest and east. The dominant trends are northwesterly, but these are crossed by several major cross-folds trending northeast.

Relatively little is known of the geology of the west half of the section. In the $\mathrm{NE} \frac{7}{4} \mathrm{NW} \frac{1}{4}$, hanging-wall strata and iron-formation are inferred largely on the basis of angle holes drilled to the northeast. The extensive area of hanging-wall rock shown on the map in the $S_{\frac{1}{2}} N W^{\frac{1}{4}}$ is based in large part on the weak positive magnetic anomaly in that area (see pl. 2). However, the inference is supported by information from the deep drill hole in the

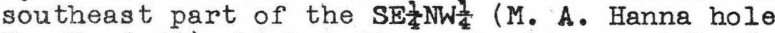
No. Do-4-44) which, after entering unoxidized iron-formation at ledge surface, passed in and out of typical hanging-wall graywacke and slate, apparently in an overturned fold.

Several shallow holes have been drilled

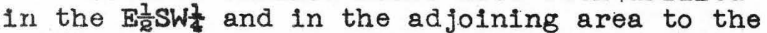
east. The core from this drilling is not available for study. Presumably most of the area is underlain by footwall strata, but whether the "green rock" referred to in the records is greenstone or a slate is not known.

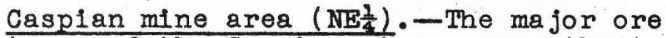
structures of the Caspian mine are north- to northwesterly-trending synclines separated by tight anticlinal folds of footwall slate (see cross section C-C', pl. 4). A major cross syncline, trending nor theasterly, crosses a short distance north of the Caspian No. I shaft. This fold is strongly overturmed to the southeast, as indicated by the west to northwest dips recorded for the eastern part of the fourth-level workings and by the cutting of magnetic slate below iron-formation in hole No. 31 in the NEtNEt sec.l. A second cross syncline, also overturned to the southeast, is present in the most southerly part of the mine, Here, in the most southerly drift of the fourth level, hanging-wall graywacke that had a northeast strike and dipped northwest was entered, and drill hole No. 56, a horizontal hole to the southeast, entered iron-formation breccia after passing through graywacke with chert fragments.

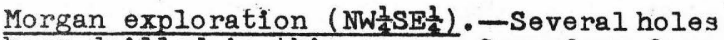
have been drilled in this area. Core from four was located and examined; hanging-wall graywacke and unoxidized to partly oxidized ironformation breccia were present in each. The most northwesterly hole entered graphitic footwall slate at ledge and then passed into unoxidized iron-formation breccia, indicating an overturned syncline.

Cottrell exploration (NEt SEl ). The Cottrell mine was developed on the northwest tip of a syncline that plunges southeasterly to merge with the Berkshire-Buck folds. Considerable drilling has been done in the remainder of the "forty", but no $\operatorname{cor} \theta$ has been retained and avaliable descriptions are meager. A major anticline of footwall, which extends northeastward. into the area north of the Berkshire mine, is present north and west of the Cottrell shaft. It is bounded successively on the northwest by iron-formation and an inferred mass of hanging-wall graywacke.

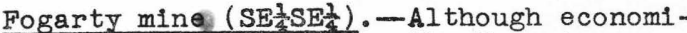
cally part of the Buck mine, the Fogarty area is a structural unit which warrants separate description. It is characterized by a series of tight, steeply-plunging folds overtumed to the southwest (dips easterly) and striking northwest. Several of the broader synclines contain hanging-wall graywacke. The steep plunges, in places as much or more than $90^{\circ}$, give the folds the exaggerated appearance of tightness shown in cross section E-E' (pl. 4).

Most of the ore occurred as sheetlike masses resting on a structural footwall of either footwall slate or overturned hangingwall graywacke. On the cross section it is seen that the iron-formation is very thin in some parts, apparently as a result of erosion at the end of iron-formation time. This thinning has resulted, in one place (see cross section), in a troughilke structure between hanging-wall and footwall strata in which the iron-formation was entirely converted to ore just as in the keel of a syncline.

A complex, dike-like mass of chloritized diabase is cut at the ninth-, tenth-, and eleventh-level stations of the Fogarty No. 1 shaft. The dike dips easterly at these lower levels and in detail cuts the footwall strata in irregular fashion, but nothing else is known of its extent. It is a massive, soft, pale-green rock, locally with reddish spots where partly oxidized. It is composed largely of very fine-grained, green chlorite.

An apparently isolated syncline of partly oxidized iron-formation is revealed by outcrops in the west part of the section (see detall map on pl. 3). The southwesterm boundary of the iron-formation is apparently a fault, inasmuch as no graphitic slate appears to intervene between the formation and the slates to the southwest.

Section 12, T. 42 N., R. 35 W., plate 3

Geologic information in sec. 12 is limited to the area of the Youngs mine, in the NEt NEt and the area immediately to the west. The mine was developed on the southeast continuation of the synclines on the Fogarty property in sec. 1. As on the Fogarty, the folds trend northwesterly and are overturned to the southwest (as shown on cross section F-F', pl. 4). Most of the ore occurred along the keel of the most southwesterly syncline, which on lower levels forms two separate "spoons" because of changes in plunge. 
The outcrops in the $\mathrm{NE}_{\frac{1}{4}}$ of the section are of a fissile, micaceous to soapy slate, gray to limonitic yellow in color. This rock is apparently stratigraphically deep in the footwall, below the sericitic slate and graywacke series.

Section 5, T. 42 N., R. 34 W., plate 3

There has been practically no exploration in section 5. Seven shallow, scattered churn drill holes provide all the direct information as to the nature of the bedrock, and no material was retained from four of these.

The magnetic survey (see pl. 2) indicates that a large part of the area is underlain by magnetic slate and associated rocks. However, a broad belt of low magnetic values trends northeasterly through the northwest part of the section; it is interpreted as indicating a fold belt which will involve principally iron-formation and footwall strata, though such folds would doubtless contain hangingwall strata locally. Although the above is the preferred explanation for the magnetic low, an alternate interpretation of the observed magnetic pattern may be suggested. The presence of the magnetic low as a border to the high magnetic anomaly could be construed as indicating that the magnetic slate (which is inferred from the high positive anomaly) is contained in a deep, northeasterlytrending syncline overturned to the southeast (dips northwest). The magnetic low would then be due to the negative effect of the lower pole of the syncline of magnetic slate. If this were true, much of the area shown on plate 3 as possibly underlain by iron-formation might actually be underlain by hangingwall strata.

The details of the structure, even on a broad scale, are necessarily obscure. The inferred iron-formation fold belt forms a northeast-trending anticlinal area between hanging-wall strata on the west and the east. The trend of the magnetic slate area to the east is in part northeast, but crest lines swing southeasterly to establish definite trends in that direction. The complicated pattern of high magnetic anomalies doubtless indicates several folds which involve the magnetic slate, but detailed analysis cannot be made.

\section{Section 6, T. 42 N., R. 34 W., plate 3}

The central part of sec. 6 is underlain by graywacke, gray slate, and graywacke with chert fragments of the hanging-wall series below the magnetic slate. The iron-formation beneath the graywacke is probably at relatively shallow depths (perhaps within a few hundred feet) in much of this area, although in a few places higher magnetic values indicate the presence of magnetic slate in deeper folds. Structural trends are difficult to establish.

The southeastern part of the section is marked by a broad magnetic low which extends northeasterly into sec. 5. Practically no bedrock information is avaliable, but it seems likely that iron-formation will be present at much of the ledge surface, probably in folds that also involve some hanging-wall strata and footwall strata at ledge. Iron-formation, if present, will be on a structure which, in a broad sense, is anticlinal, and whether or not it is oxidized is a matter of some doubt.

Borland exploration $\left(N \frac{1}{2} N W^{\frac{1}{4}}\right)$. - All the drill holes in this area cut iron-formation or hanging-wall strata; none entered the footwall slates. The most easterly hole, No. 11 of this exploration, entered magnetic slate at ledge surface and continued in it for more than 300 feet before entering hanging-wall gray slates, graywacke, and graywacke with chert fragments. Breccia, both in the ironformation and the graywacke, is abundant in the area and was cut in many of the holes, although silty ferruginous slates appear to predominate in the hanging wall immediately above the iron-formation.

Sections indicate wholesale overtuming on both northwesterly-trending folds and on cross folds. As a result, it has not been found possible to adequately rationalize detalls of the structure from the avaliable data.

Corry exploration (NEtSW face holes in this "forty" entered hangingwall strata at ledge surface. Massive, oxidized graywacke is dominant, although some fermuginous slate is commoniy present in most places. The deeper holes and the underground workings (which were opened as eastward extensions of the lower levels of the Berkshire mine) entered oxidized iron-formation, locally with some ore, and holes No. 8 (most northwesterly surface hole) and McEachern hole No. 14 (from the first level of the Corry shaft) cut fotwall strata about 500-600 feet below surface. A long horlzontal drill hole (Corry No. 14), drilled southeasterly from the "642" level of the workings, passed from hanging-wall graywacke into footwall slate at a point approximately 700 feet northwest of

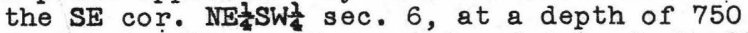
feet below the surface, and ended in footwall slate about 200 feet northwest of that corner. The contact between these two rocks is apparently a fault which cuts out the iron-formation.

Dominant trends in the area appear to be nearly east-west, at least in the western part; the folds are steep, possibly overturned slightly to the south. The iron-formation was well oxidized, but apparently thin - about 50 to 75 feet thick.

Berkshire mine (NW $\left.\frac{1}{4} W^{\frac{2}{4}}\right)$ :- Most of the ore bodies in the upper levels of the Berkshire mine were located on two east-west trending synclines overtumed to the north. In the deeper workings, a tight buckle of footwall slate made its appearance as an "island" between these two northernmost synclines. On the "642" level this buckle connects with the main footwall slate area to the north and divides the synclines (which in the upper levels had an east-west trend) into two major structures which assume a north to northeasteriy trend. These synclines plunge to the south and connect with the major synclines of the Buck mine.

North of the Berkshire shaft is a major anticline of footwall slate. The iron-formation on the north side of this anticline has been explored in but one place, namely, by a 
long hole (No. 3) extending northeast from the "3f5" level to the northeast comer of the 1. $\frac{1}{4}$ sec. 6. This hole, after cutting more than a thousand feet of folded footwall strata, entered partly-oxidized iron-formation.

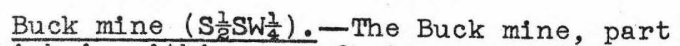
of which is within sec. 6 , is one of the largest producers in the district. Operated from the Berkshire, Baltic, and Fogarty shafts, it is now on the eleventh level (1,000 feet below surface) and covers parts of seven "forties".

The only ore on the upper levels of this part of the Buck mine occurred as northeasttrending bodies resting on a structural footwall of hanging-wall graywacke dipping to the northwest, as shown in cross section $D^{\prime} D^{\prime}$ and E-E! (pl. 4). The graywacke, which occurs in a northeast-trending, northeast-pitching, overtumed cross fold, merges with the larger area of hanging-wall strata to the northeast (pl. 3). It will be noted from the magnetic map (p1. 2) that this area of graywacke is marked by slightly higher magnetic values than those over iron-formation and footwall rock, and that the zero isomagnetic contour is in general close to the iron-formation hangingwall contact. Underground, this cross syncline, together with others to the north which are subparallel, intersect northwest-trending synclines about in the center of the SW $\frac{1}{4} S W \frac{1}{4}$ to produce, on the tenth level, two isolated basins of iron-formation surrounded by footwall beds. The relations between the northwesterly-trending folds and the northeasterlytrending folds are illustrated by cross sections $D-D^{\prime}$ and $E-E^{\prime}$ (pI. 4).

On lower levels, the deep, northwesttrending synclines of the adjacent Fogarty property, that are overtumed to the west, pass into the Buck area, but the major structures containing iron-formation are in the eastern part of the SW $\frac{1}{4} S W_{\frac{1}{4}}$. These folds trend northwesterly. It will be noted from cross section $D-D^{\prime}$ that the ore bodies that rested on a structural footwall of graywacke in the upper levels died out with depth as the dips of the overturned graywacke steepened and then became normal, and that the ore did not connect with that resting on the footwall of the major troughs.

A long horizontal hole (No. 40) drilled east from the tenth 1 vel to the north-south center line of sec. 6 shows that the eastern part of the SW $\frac{1}{4} S W_{\frac{1}{4}}$ at this depth is hangingwall graywacke which continues about 400 feet into the adjacent $\mathrm{SE} \frac{1}{4} \mathrm{SW} \frac{1}{4}$, where it is in fault contact with footwall slate. Inasmuch as neither the trend nor the dip of this fault is known, it is not shown on the map (pl.3). The remainder of the hole is in footwall for several hundred feet and then enters unoxidized iron-formation breccia.

The structure in the southeast art of the SW SW $_{4}^{\frac{1}{4}}$ is not clearly understood The most so the s erly surface ho e, No 23, en e ed footwall r phitic slate th ulface nd continued in footwall to a d pth of about 850 feet. Be ow his, it was in graywacke, which resembles hanging-wall strata, to the bottom at 1,100 feet. Thus far, no adequate structural explanation can be found which rati nal.. izes the presence of footwall slate at the surface with the geology shown in the underground workings, although a northeast-trending fault of large displacement may be indicated. Such a fault might pass into bedding-plane shear to the southwest along the northeast-trending, tight folds of the Baltic mine.

\section{Section 7, T. 42 N., R. 34 W., plate 3}

The north half of sec. 7 is underlain predominantly by iron-formation and hangingwall strata. The strong magnetic anomaly in

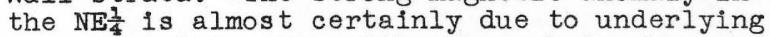
magnetic slate, for although no holes have been drilled in this section in the area of strong anomaly, a hole in the east part of sec. 8, drilled on the south flank of an anomaly that is nearly continuous into the sec. 7 high, cuts typical banded cherty magnetic slate. The magnetic low which borders the high positive anomaly is interpreted as indicating iron-formation at ledge surface. However, as for the sec. 5 magnetic low, it is possible that this magnetic low actually is due to the effect of the lower pole of a deep, overturned syncline of magnetic slate, the upper pole of which yields the high positive anomaly.

The south half of the section appears to be almost entirely underlain by footwall strata, although questionable iron-formation was reported in one hole in the NEt SW of the remainder of the holes entered what is described in the records as "gray slate." None of this core was available for examination.

Baltic mine (NW $\frac{1}{4} N W^{\frac{1}{4}}$ ). - The Baltic mine was developed on a series of tight, steeplyplunging, closely-spaced folds trending northeast, athwart the dominant northwest trends of the adjacent areas. Viewed broadly, the Baltic area is anticlinal at ledge surface, inasmuch as the folds bring footwall strata to the surface with iron-formation and hangingwall strate on either side. However, the synclines are very deep, so that 1 , ooo feet below the surface some of them still contain iron-formation whereas adjacent synclines, which at the surface contained hanging-wall graywacke, at that depth have bottomed in the footwall slate. Cross section F-F' (pl. 4) shows some of these relations.

The total width of the Baltic fold belt is not more than about 800 feet. The footwall strata separating the synclines form narrow, highly-sheared anticlines, so that in many respects, the Baltic folds are closely analogous to faults. There are indications that a fault (or faults) with this same northeasteriy trend cuts the more competent strata to the northeast.

Zimmerman mine area ( $\left.B \frac{1}{2} N W \frac{1}{4}\right)$. - As shown in eross section G-G' (pl. 4), the Zimmerman mine was developed in a series of drag folds that progressively deepened to the north. In the Zimmerman mine itself, many of the folds are overturned to the south; north of this area, however, overtuming to the north is indicated. Plunges are variable, but in the east part of the mine area, the folds plunge eastward into the adjacent DeGrasse property. 


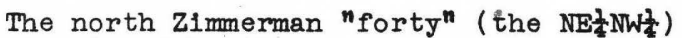
was not entered by the Zimmerman mine workings but was entered by the tenth level of the Buck mine. Several deep holes have been drilled from the surface; most cut hanging-wall graywacke or slate at ledge surface and some entered iron-formation at depth. The deep basin of hanging-wall strata thus indicated is shown on the cross section. The iron-formation is believed to be present at surface in the northern part of the area partly because the rock encountered at ledge in drill hole No. $C-43$ (see cross section $G-G^{\prime}$ ) is a sideritic slate of the type commonly found immediately above the iron-formation. The two shallow holes in the northwest corner of the NE $\frac{1}{4} N W \frac{1}{4}$ (drilled from the same location) cut what was described as "black slate and chert." It is possible that this, is actually unoxidized iron-formation, inasmuch as much of the ironformation cut at depth by the tenth level of the Buck mine is unoxidized.

It will be noted from the magnetic map (pl. 2) that the deep basin of hanging wall strata shown on cross section G-G' (pl. 4) does not give the uniformly higher magnetic values that might be expected. The reason for this is not clear; possibly it is due to the influence of basement rocks, but more likely it is due to cultural objects which make the magnetic determinations unreliable.

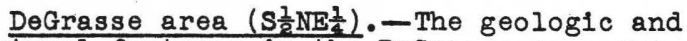
structural features in the DeGrasse area are similar in most respects to those of the adjoining zimmerman area to the west, and most of the mining was carried on as an eastward extension of the Zimmerman mine. The DeGrasse shaft was shallow, and no ore was produced from it.

As shown on cross section $\mathrm{H}^{-\mathrm{H}^{\prime}}$ (pl. 4), the mining operations were largely confined to a single, rather complex syncline that is one of a series of drag folds that deepen to the north. However, from the magnetic data, it is believed that an unexposed belt of iron-formation may reach ledge surface north of the explorations and south of the high magnetic anomaly. A single shallow churn-drill hole cut at ledge what was described as "black slate," which contained about 20 percent iron.
Section 8, T. 42 N., R. 34 W., plate 3

Two strong belts of magnetic anomaly cross the northern part of sec. 8 (see pl. 2); both are doubtless caused by the magnetic slate. The magnetic slate was cut at ledge in the most northerly drill hole in the $\mathrm{NE}_{\frac{1}{4}} \mathrm{SE} \frac{1}{4}$. A magnetic low in the northwest corner of the section is interpreted to indicate iron-formation folds at ledge, as in the magnetic low in sec. 7, although the only hole drilled (a churn-drill hole) cut black slate.

Detalled interpretation of the magnetic data in the southern part of the section is impossible because of the change in magnetic base level, discussed earlier under "Interpretation of the magnetic data." This change is belleved to be due to change in character of the basement greenstone rocks. In the absence of help from the magnetics, little can be done other than to rationalize the avallable drill-hole data, such as was done on plate 3.

W홍 Section 9, T. 42 N., R. 34 W., plate 3

Magnetic values in the northern threefourths of the W $W^{\frac{1}{2}}$ sec. 9 are high (see pl. 2), and the area is believed to be underlain entirely by hanging-wall strata and magnetic slate. The two drill holes in the NEtsWt cut typical hanging-wall graywacke. The drill hole located 1,400 feet south of the center sec. 9 , is like the others in this area, a shallow hole, and only a few pleces of core were preserved. The rock is a banded, cherty, sideritic slate, which, except that it is nonmagnetic, is very similar to the lower part of the magnetic slate elsewhere. As can be seen from the map, the hole is close to the crest line of a magnetic anomaly, so it seems likely that the hole was in a nonmagnetic zone within the magnetic slate.

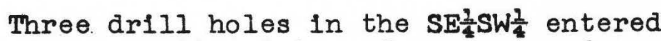
footwall graphitic slate and one entered unoxidized iron-formation. South of the map area, other holes entered unoxidized ironformation.

The four maps may be obtained for $\$ 1.40$ per set from the Director, U. S. Geological Survey, Washington 25, D. C. 